\title{
Trehalose-Based Block Copolycations Promote Polyplex Stabilization for Lyophilization and in Vivo pDNA Delivery
}

Zachary P. Tolstyka, ${ }^{\dagger}$ Haley Phillips, ${ }^{\dagger}$ Mallory Cortez, ${ }^{\dagger, \star}$ Yaoying Wu, ${ }^{\dagger} \S$ Nilesh Ingle ${ }^{\dagger}$ Jason Bell, ${ }^{€}$ Perry Hackett, ${ }^{€}$ and Theresa M. Reineke ${ }^{\dagger} * *$

${ }^{\dagger}$ University of Minnesota, Department of Chemistry and Center for Genome Engineering, 207

Pleasant Street SE, Minneapolis, MN 55455.

${ }^{€}$ University of Minnesota, Department of Genetics, Cell Biology and Development, and Center for Genome Engineering, Minneapolis, MN 55455.

\$Current Address: Department of Physical Sciences, Nicholls State University, Thibodaux, LA, 70310.

${ }^{\S}$ Current Address: University of Chicago, Department of Surgery, 5812 S. Ellis Ave, Chicago, IL, 60637.

*To whom correspondence should be addressed: treineke@umn.edu 


\section{Supplementary Information}

\section{Materials}

All reagents were obtained at the highest available purity from Thermo Fisher Scientific, Inc. (Pittsburgh, PA) or Sigma-Aldrich Co. LLC. (St. Louis, MO) and used as received unless noted otherwise. jetPEI was obtained from Polyplus-transfection SA (Illkirch, France). Glycofect was obtained from Techulon, Inc. via donation. 6-Methacrylamido-6-deoxy trehalose (MAT) was synthesized as previously described. ${ }^{1}$ Propidium iodide, UltraPure ${ }^{\mathrm{TM}}$ Agarose-1000, trypsin, (3(4,5-dimethylthiazol-2-yl)-2,5-diphenyl tetrazolium bromide (MTT), phosphate-buffered saline (PBS), Minimum Essential Medium with reduced serum (Opti-MEM), and Dulbecco's Modified Eagle Medium (DMEM) were purchased from Life Technologies - Thermo Fisher Scientific (Carlsbad, CA). The pT2/CaL plasmid was prepared as previously described. ${ }^{2}$ The Luciferase Assay Kit and cell lysis buffer were obtained from Promega Corporation (Madison, WI). BioRad DC Protein Assay Reagent A, Reagent B and Reagent S were obtained from Bio-Rad Laboratories, Inc. (Hercules, CA). HepG2 and U87 cells were obtained from the American Type Cell Culture Collection (ATCC) (Manassas, VA). The cells were grown in complete DMEM [supplemented with 10\% (v:v) fetal bovine serum and 1\% antibiotic-antimycotic solution (containing penicillin, streptomycin, and amphotericin B)] at $37^{\circ} \mathrm{C}$ and $5 \% \mathrm{CO}_{2}$ in a humidified incubator.

\section{$\underline{\text { Instrumentation }}$}

NMR spectra were recorded using a Bruker Avance III HD $500 \mathrm{MHz}$ spectrometer in $\mathrm{D}_{2} \mathrm{O}$ purchased from Cambridge Isotope Laboratories, Inc. (Andover, MA). NMR data was analyzed using Bruker Top Spin version 3.1. UV-Vis data was collected with an Ocean Optics Inc. CUV 1 cm cuvette holder powered by a Mikropack DH-2000 Deuterium/Halogen open-close TTC lamp, and data was analyzed by Ocean Optics Inc. Basic Acquisition Software.

Size exclusion chromatography (SEC) was conducted using an Agilent 1260 High Performance Liquid Chromatograph running $1.0 \mathrm{wt} \%$ acetic acid/0.1 $\mathrm{M} \mathrm{Na}_{2} \mathrm{SO}_{4}$ as the eluent at a flow rate 0.4 $\mathrm{mL} / \mathrm{min}$ on size exclusion chromatography columns [CATSEC1000 (7 $\mu, 50 \times 4.6)$, CATSEC100 $(5 \mu, 250 \times 4.6)$, CATSEC300 $(5 \mu, 250 \times 4.6)$, and CATSEC1000 $(7 \mu, 250 \times 4.6)]$ obtained from 
Eprogen Inc. (Downers Grove, IL). Signals were acquired using Wyatt HELEOS II light scattering detector $(\lambda=662 \mathrm{~nm})$, and an Optilab $\mathrm{rEX}$ refractometer $(\lambda=658 \mathrm{~nm})$. SEC trace analysis was performed using Astra VI software (version 5.3.4.18), Wyatt Technologies (Santa Barbara, CA). Hydrodynamic diameter of the polyplexes was recorded via dynamic light scattering measurements (DLS) with a Malvern Zatasizer Nano ZA. MTT, protein, and luciferase assays were measured with a BioTek Synergy H1 plate reader (BioTek Instruments, Inc., Winooski, VT). Cy5-uptake was measured on a FACSVerse (Becton Dickenson Biosciences, San Jose, CA) flow cytometer. TEM images were obtained with a FEI Tecnai G2 Spirit BioTWIN (FEI, Hillsboro, OR) transmission electron microscope, operated at $120 \mathrm{kV}$.

Live animal and animal tissue imaging were performed on an IVIS Spectrum In Vivo Imaging system and data was analyzed with the Living Image software (PerkinElmer Inc., Waltham, MA). RT-qPCR was performed using an Eppendorf Mastercycler (software version 2.2; Eppendorf).

Statistical analysis was performed using JMP Pro Software (SAS Institute, Cary, NC) through the University of Minnesota Supercomputing Institute.

\section{Polymer Synthesis}

\section{Synthesis of poly(methacrylamidotrehalose) (pMAT 43 )}

pMAT 43 was synthesized as previously described. ${ }^{1}$ Briefly, MAT (0.765 g, $\left.1.867 \mathrm{mmol}, 65 \mathrm{eq}\right)$ was dissolved in $7.00 \mathrm{~mL}$ of $0.1 \mathrm{M}$ acetate buffer $(\mathrm{pH}=5.5)$. 4-cyano-4(propylthiocarbonothioylthio)-pentanoic acid (CPP) (7.97 mg, 2.87x10-2 mmol, 1 eq) was dissolved in $645 \mu \mathrm{L}$ of MeODH and added to the MAT solution, followed by 4,4'-azobis(4cyanovaleric acid) (V-501) (0.805 mg, 2.87x10-3 mmol, $0.1 \mathrm{eq})$ in $244 \mu \mathrm{L}$ of methanol (MeOH). Finally, $861 \mu \mathrm{L}$ of $\mathrm{MeOD}$ was added to a final volume of $1.75 \mathrm{~mL}$ of $\mathrm{MeOH}$. Oxygen was removed by bubbling nitrogen for $45 \mathrm{~min}$. The flask was heated to $70{ }^{\circ} \mathrm{C}$ for $6 \mathrm{~h}$ and the reaction was stopped by removing the septum and cooling the reaction mixture on ice. The polymer solution was dialyzed against ultra-pure water (3500 Da MWCO) acidified to $\mathrm{pH}$ 4-5 with $\mathrm{HCl}$. Water changes were performed every $4 \mathrm{~h}$. After $3 \mathrm{~d}$ of dialysis, the polymer solution was freeze 
dried on a VirTis benchtopK lyophilizer at $62 \mathrm{mT}$ with the condenser at $-57.4^{\circ} \mathrm{C}$ lyophilized to yield $454 \mathrm{mg}$ of white solid.

SEC (eluent: $1.0 \mathrm{wt} \%$ acetic acid $/ 0.1 \mathrm{M} \mathrm{Na}_{2} \mathrm{SO}_{4}$ ). A flow rate of $0.4 \mathrm{~mL} / \mathrm{min}$, light scattering detector $(\lambda=662 \mathrm{~nm})$ and refractometer $(\lambda=658 \mathrm{~nm})$. Mn=17.7 kDa, degree of polymerization (n) $=42.5 \sim 43$, PDI $=1.06$.

${ }^{1} \mathrm{H}-\mathrm{NMR}\left(500 \mathrm{MHz}, \mathrm{D}_{2} \mathrm{O}\right) \delta \mathrm{ppm}: 5.26-4.96$ (bs, 86H), $4.00-3.04(\mathrm{~m}, 516 \mathrm{H}), 2.35-2.21$ (bs, $2 \mathrm{H}), 1.79-0.61(\mathrm{~m}, 217 \mathrm{H})$.
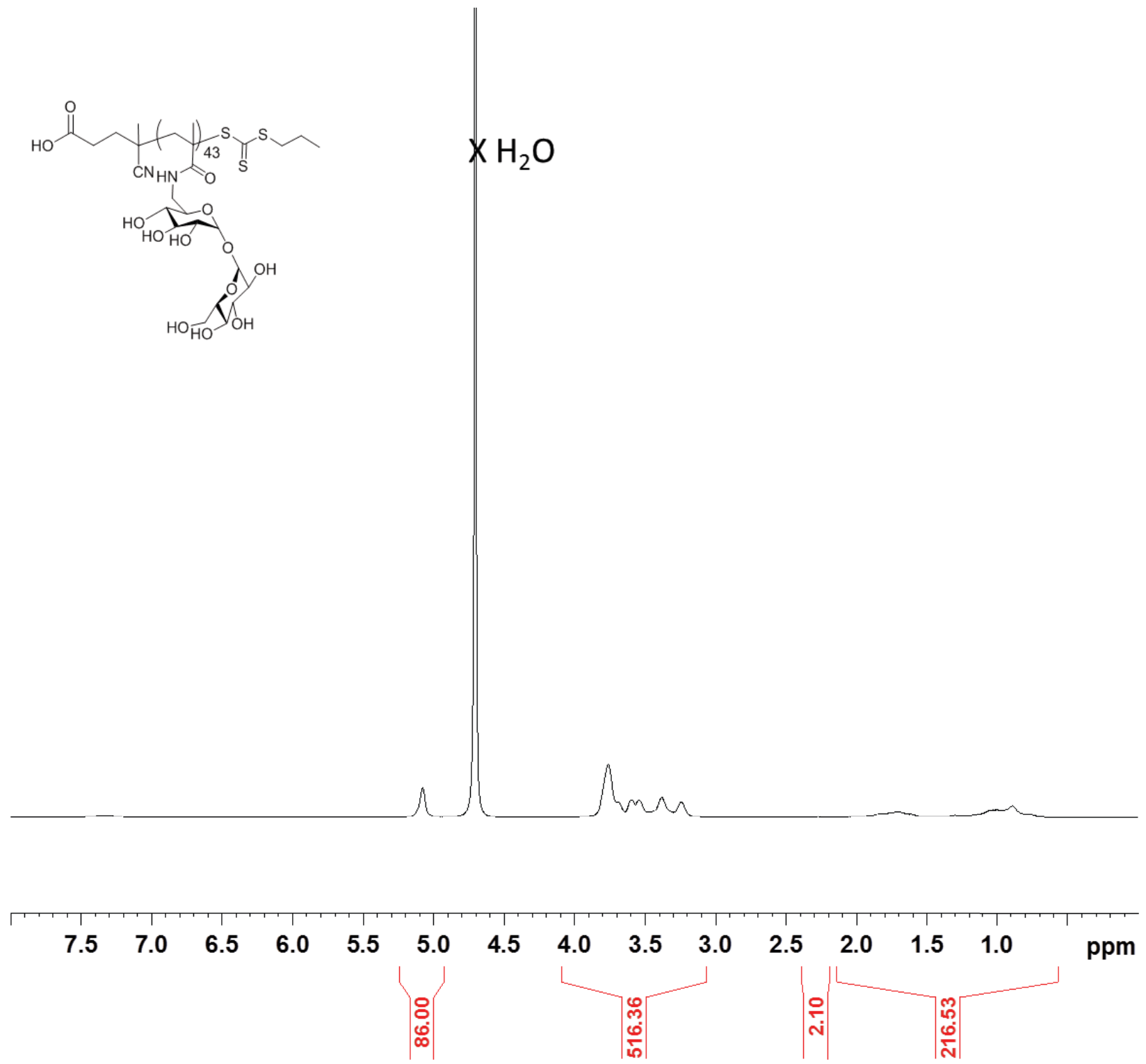

Figure S1. ${ }^{1} \mathrm{H}$ NMR spectrum of $\mathbf{p M A T}_{43}$. 


\section{Synthesis of cationic diblock copolymers pMAT-b-AEMA 1-3}

Cationic diblock copolymers were synthesized as previously reported. ${ }^{1}$ Briefly, pMAT $_{43}(327$ $\left.\mathrm{mg}, 1.56 \times 10^{-2} \mathrm{mmol}, 1.00 \mathrm{eq}\right)$ was dissolved in $3.00 \mathrm{~mL}$ of $1.0 \mathrm{M}$ acetate buffer $(\mathrm{pH}=5.5)$ and added to a schlenk tube containing aminoethylmethacrylamide hydrochloride (AEMA $\cdot \mathrm{HCl}$, $311 \mathrm{mg}, 1.89 \mathrm{mmol}, 121 \mathrm{eq})$. V-501 (0.44 mg, 1.56x10-3 mmol, $0.10 \mathrm{eq})$ was dissolved in 0.78 $\mathrm{ml}$ of $1.0 \mathrm{M}$ acetate buffer $(\mathrm{pH}=5.5)$ and added to the schlenk tube prior to sealing the tube. Deoxygenation was achieved via bubbling nitrogen gas for $45 \mathrm{~min}$. The tube was heated to 70 ${ }^{\circ} \mathrm{C}$. Aliquots $(1.25 \mathrm{~mL}$ ) were removed via syringe at $30 \mathrm{~min}$ (pMAT-b-AEMA-1) and $60 \mathrm{~min}$ (pMAT-b-AEMA-2). Each aliquot was exposed to air and cooled in liquid nitrogen to stop polymerization. After 90 min (pMAT-b-AEMA-3), the reaction was halted by septum removal and submerging the schlenk tube in liquid nitrogen. All three copolymers were dialyzed (3500 Da MWCO) against $3 \times 4 \mathrm{~L}$ of $0.5 \mathrm{M} \mathrm{NaCl}$ solution, followed by $3 \times 4 \mathrm{~L} 0.1 \mathrm{M} \mathrm{NaCl}$ and finally $6 \mathrm{x} 4 \mathrm{~L}$ of ultra-pure water. All dialysis media were acidified with $\mathrm{HCl}$ to $\mathrm{pH} 4-5$. Polymer solutions were lyophilized as described above to yield white, flocculent powders. All experiments were completed using polymers pMAT-b-AEMA-1, -2, and -3.

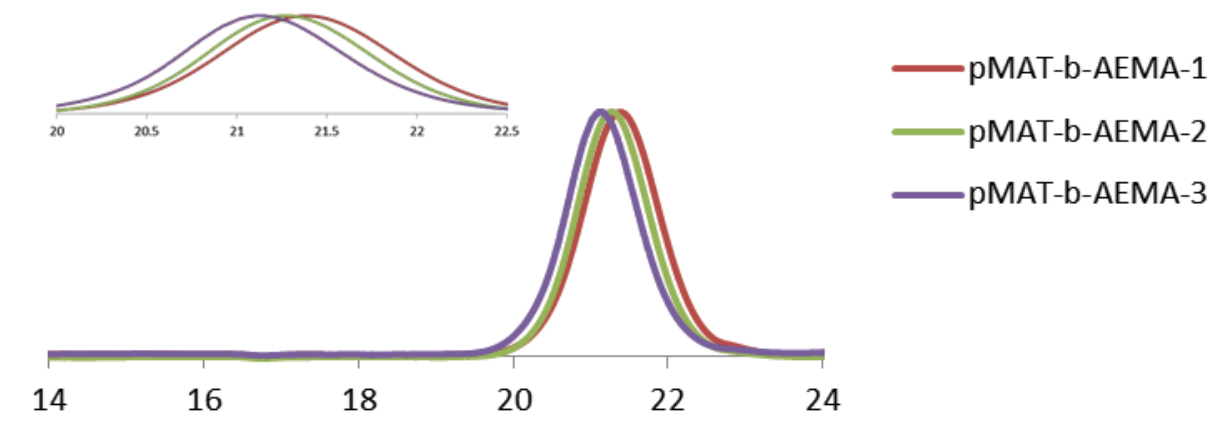

Figure S2. GPC traces of pMAT-b-AEMA series of polymer. Lower retention time indicates higher molecular weight. 
MAT $_{43}-b-\mathrm{AEMA}_{21}$ (pMAT-b-AEMA-1), SEC (eluent: $1.0 \mathrm{wt} \%$ acetic acid/0.1 $\mathrm{M} \mathrm{Na}_{2} \mathrm{SO}_{4}$ ). A flow rate of $0.4 \mathrm{~mL} / \mathrm{min}$, light scattering detector $(\lambda=662 \mathrm{~nm})$ and refractometer $(\lambda=658 \mathrm{~nm})$. $\mathrm{Mn}=20.4 \mathrm{kDa}, \mathrm{PDI}=1.07$.

${ }^{1} \mathrm{H}$ NMR (500 MHz, $\left.\mathrm{D}_{2} \mathrm{O}\right) \delta$ ppm: $5.18-4.97$ (bs, 86H), $3.94-2.94(\mathrm{~m}, 600 \mathrm{H}), 2.03-1.49(\mathrm{~m}$, 64H), $1.16-0.66(\mathrm{~m}, 192 \mathrm{H})$.
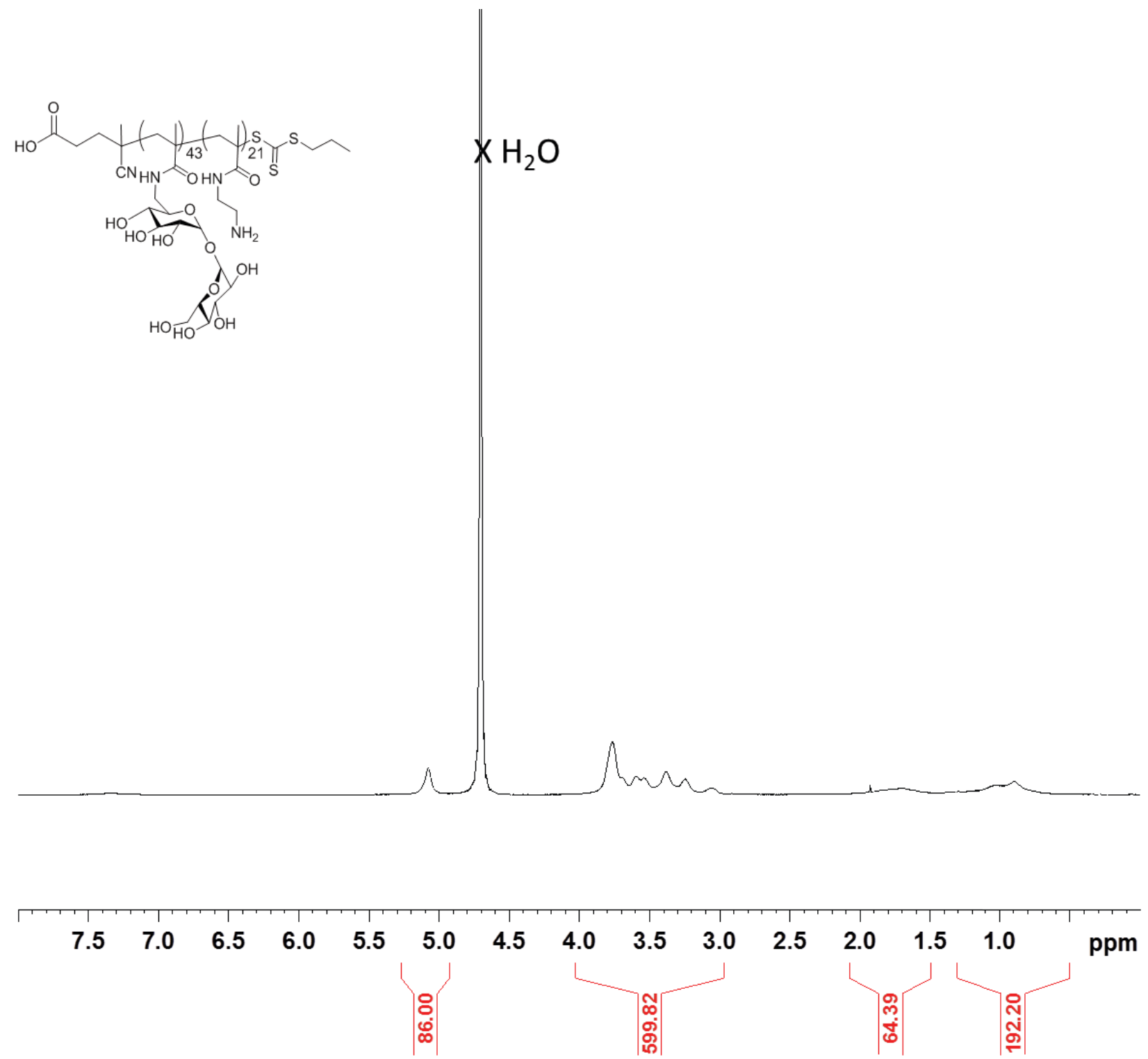

Figure S3. ${ }^{1}$ H NMR spectrum of pMAT-b-AEMA-1. 
MAT $_{43}-b-\mathrm{AEMA}_{44}(\mathbf{p M A T - b - A E M A - 2})$, SEC (eluent: $1.0 \mathrm{wt} \%$ acetic acid/0.1 $\mathrm{M} \mathrm{Na}_{2} \mathrm{SO}_{4}$ ). A flow rate of $0.4 \mathrm{~mL} / \mathrm{min}$, light scattering detector $(\lambda=662 \mathrm{~nm})$ and refractometer $(\lambda=658 \mathrm{~nm})$. $\mathrm{Mn}=23.3 \mathrm{kDa}, \mathrm{PDI}=1.07$.

${ }^{1} \mathrm{H}$ NMR (500 MHz, $\left.\mathrm{D}_{2} \mathrm{O}\right) \delta$ ppm: $5.18-4.97$ (bs, 86H), $3.94-2.94$ (m, 689H), 2.03-1.49 (m, $87 \mathrm{H}), 1.16-0.66(\mathrm{~m}, 224 \mathrm{H})$.
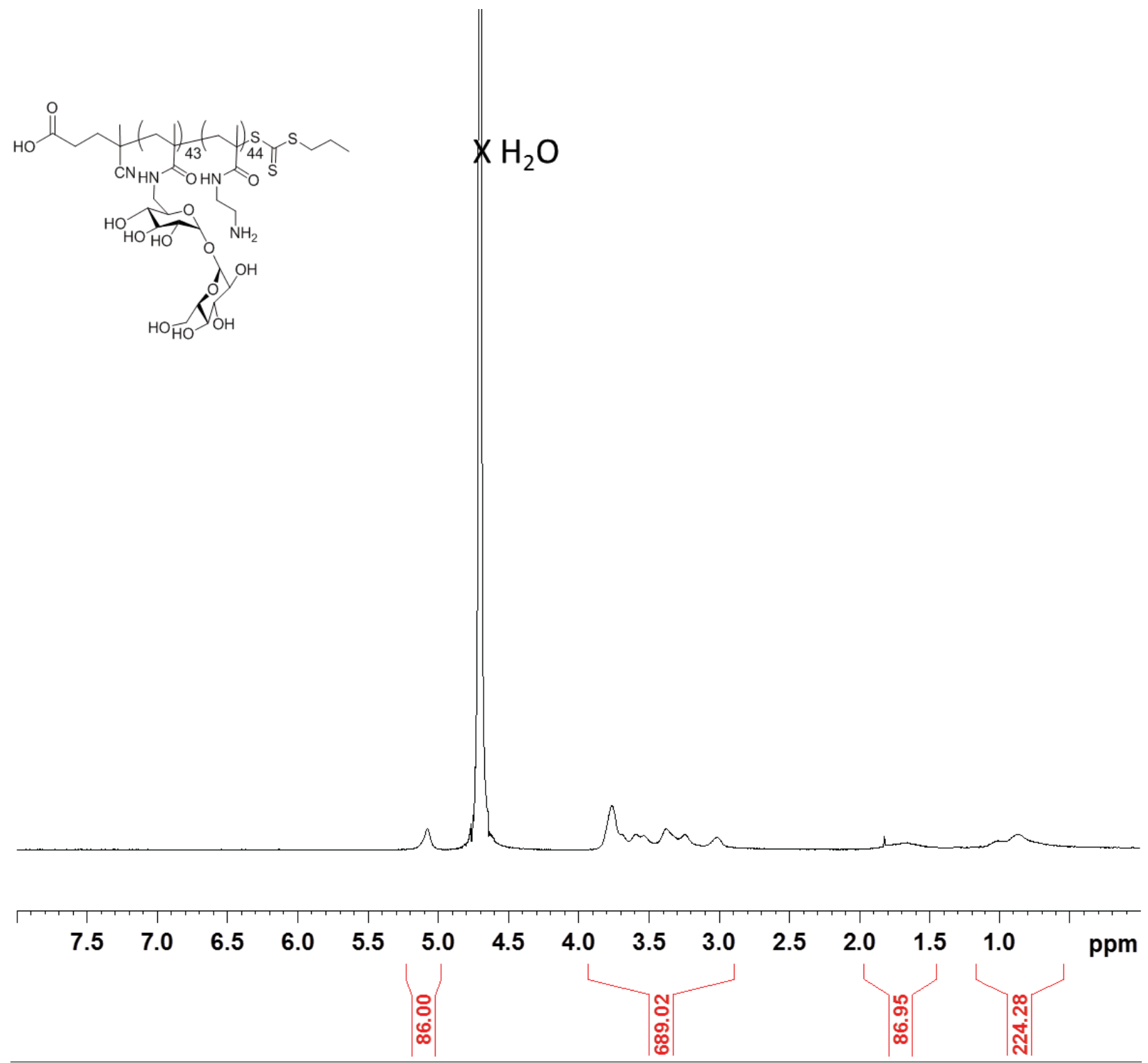

Figure S4. ${ }^{1}$ H NMR spectrum of pMAT-b-AEMA-2. 


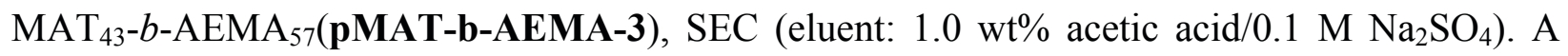
flow rate of $0.4 \mathrm{~mL} / \mathrm{min}$, light scattering detector $(\lambda=662 \mathrm{~nm})$ and refractometer $(\lambda=658 \mathrm{~nm})$. $\mathrm{Mn}=25.0 \mathrm{kDa}, \mathrm{PDI}=1.08$.

${ }^{1} \mathrm{H}$ NMR (500 MHz, D $\left.2 \mathrm{O}\right) \delta$ ppm: 5.18 - 4.97 (bs, 86H), $3.94-2.94$ (m, 744H), 2.03-1.49 (m, $100 \mathrm{H}), 1.16-0.66(\mathrm{~m}, 300 \mathrm{H})$.
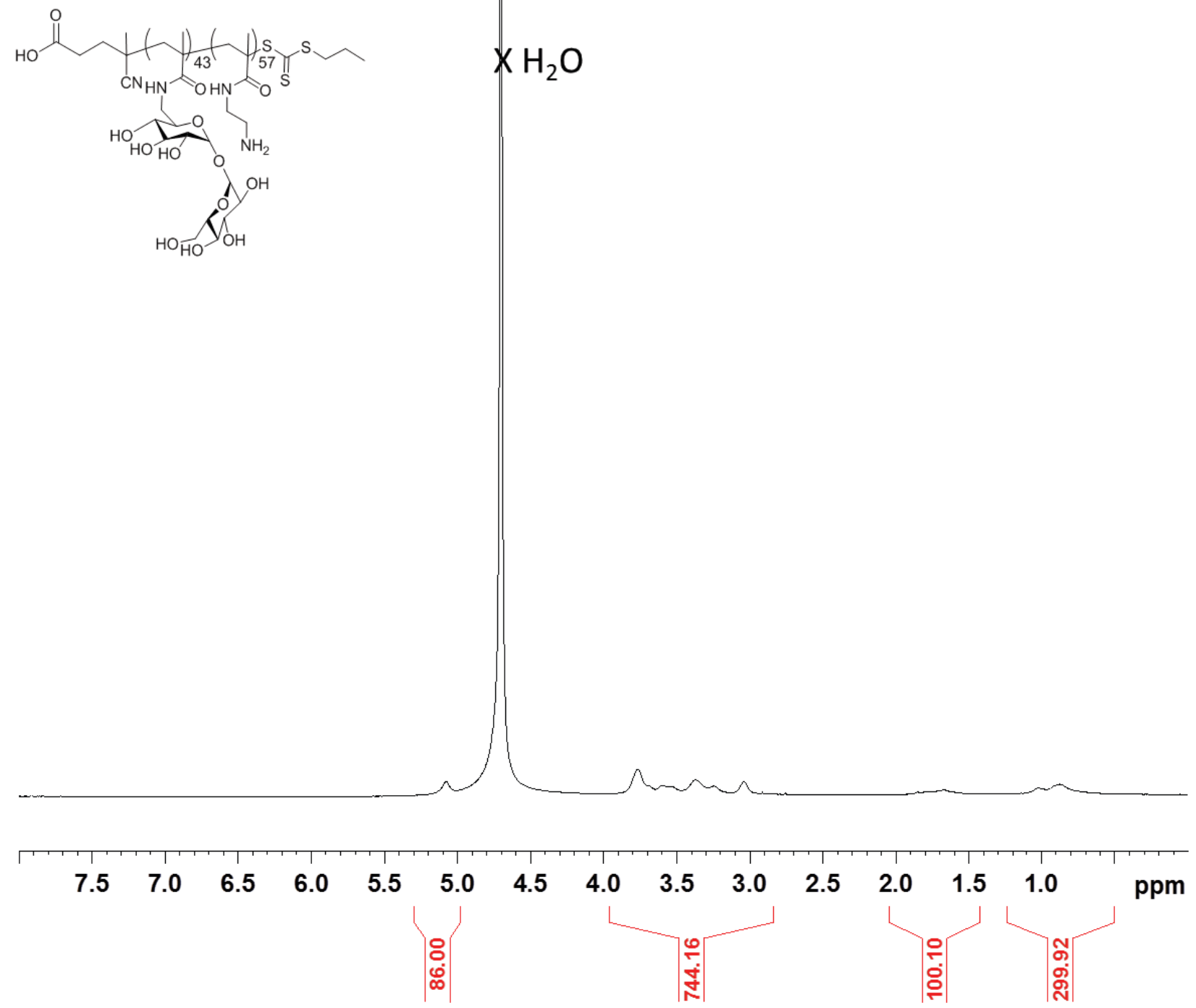

Figure S5. ${ }^{1}$ H NMR spectrum of pMAT-b-AEMA-3. 


\section{Synthesis of Cy7-pMAT-b-AEMA-2}

The polymer was labeled using an NHS-Cy7 fluorophore. pMAT-co-AEMA-2 (10.0 mg, 4.30x $10^{-4}$ mmol, $0.0190 \mathrm{mmol}$ primary amine) was dissolved in $900 \mu \mathrm{L}$ of $\mathrm{H}_{2} \mathrm{O}$. Cy7 functionalized with N-hydroxysuccinamide (NHS-Cy7) in DMF (26 $\mu \mathrm{L}, 1.0 \mathrm{mg} / 10 \mu \mathrm{L}, 0.00038$ mmol) was added followed by $97.4 \mu \mathrm{L}$ of DMF to target 1 fluorophore/50 amine residues. The mixture was vortexed for $30 \mathrm{~s}$ and allowed to proceed for $4 \mathrm{~h}$ in the dark. The labeled polymer was purified via dialysis (3500 MWCO) against $\mathrm{H}_{2} \mathrm{O}$ (acidified to $\mathrm{pH} \sim 5.5$ with $\mathrm{HCl}$ ) for 2 days and lyophilized using the same conditions listed before to yield a blue flocculent solid.

Extent of labeling was quantified measuring the absorbance of a $0.2 \mathrm{mg} / \mathrm{mL}$ of labeled polymer in $\mathrm{H}_{2} \mathrm{O}$ at $750 \mathrm{~nm}$ via $\mathrm{UV}-\mathrm{Vis}(\varepsilon=199000$ at $750 \mathrm{~nm}, \mathrm{Abs}=0.16$, Figure S2 $)$ giving approximately $1 \mathrm{Cy} 7$ fluorophore / 10 polymer chains.

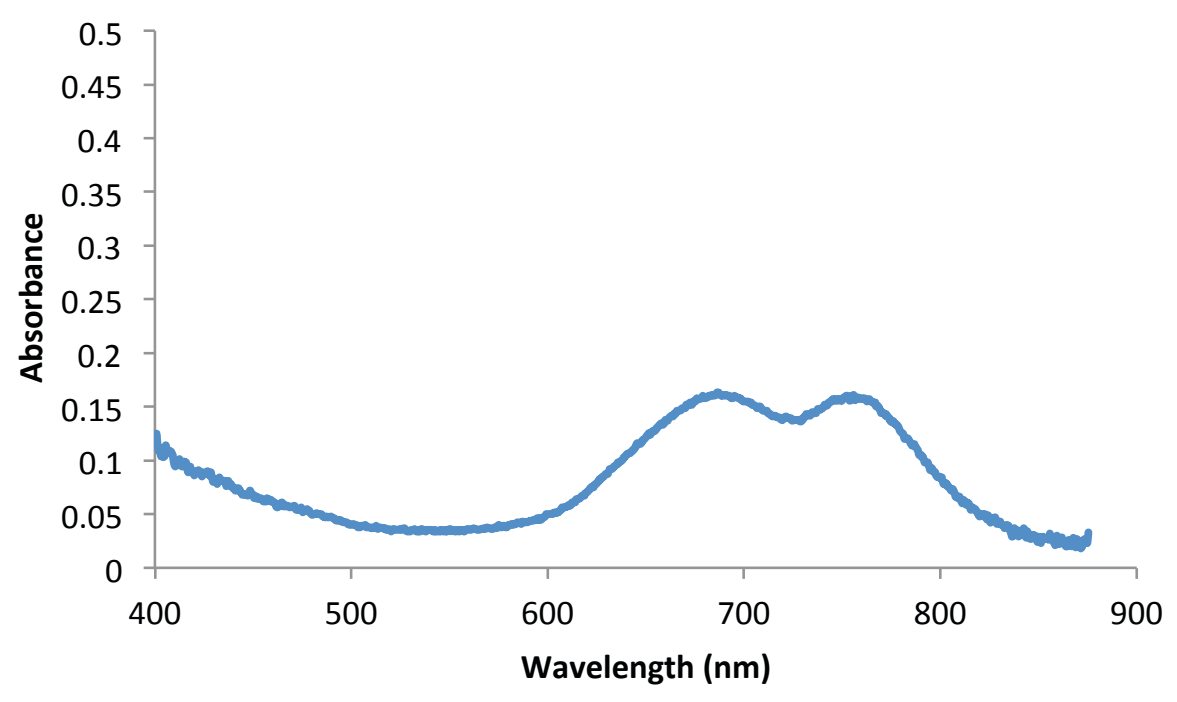

Figure S6. Absorbance of Cy7-pMAT-b-AEMA-2 in $\mathrm{H}_{2} \mathrm{O}$ used to calculate labeling efficiency ( $\sim \mathrm{Cy} 7$ per 10 polymer chains) from the extinction coefficient for NHS-Cy7 (provided by the manufacturer, Lumiprobe Corp.). 
Polyplex Formation For Gel Electrophoresis and Tissue Culture (In Vitro) experiments

Polymer solution at an appropriate concentration in water was added to a $400 \mu \mathrm{M}$ solution of pDNA in DNase/RNase-free distilled water in an equal volume to yield polyplexes of (nitrogen to phosphate ratios) $\mathrm{N} / \mathrm{P}=7,14$, and 21 at a final concentration of $200 \mu \mathrm{M}$. The nitrogen ratios were calculated based on the concentrations of amines (either pendant from AEMA blocks or within the backbone of jetPEI or Glycofect). The solutions were incubated at $23{ }^{\circ} \mathrm{C}$ for $1 \mathrm{~h}$ prior to further use.

\section{Gel Electrophoresis}

A gel electrophoresis mobility shift assay was run to determine the minimal amount of polymer needed to achieve complete binding of the pDNA. $10 \mu \mathrm{L}$ of each polyplex solution formulated at various $\mathrm{N} / \mathrm{P}$ ratios were formulated and diluted with $10 \mu \mathrm{L}$ of water to achieve a concentration of $100 \mu \mathrm{M}$ and were incubated at $25{ }^{\circ} \mathrm{C}$ for $1 \mathrm{~h}$ to allow polymer-pDNA binding. The polyplex suspensions were run on agarose gels $(0.6 \%)$ containing $6 \mu$ g ethidium bromide at 60 volts for 80 min. Images were obtained using $312 \mathrm{~nm}$ UV light. 


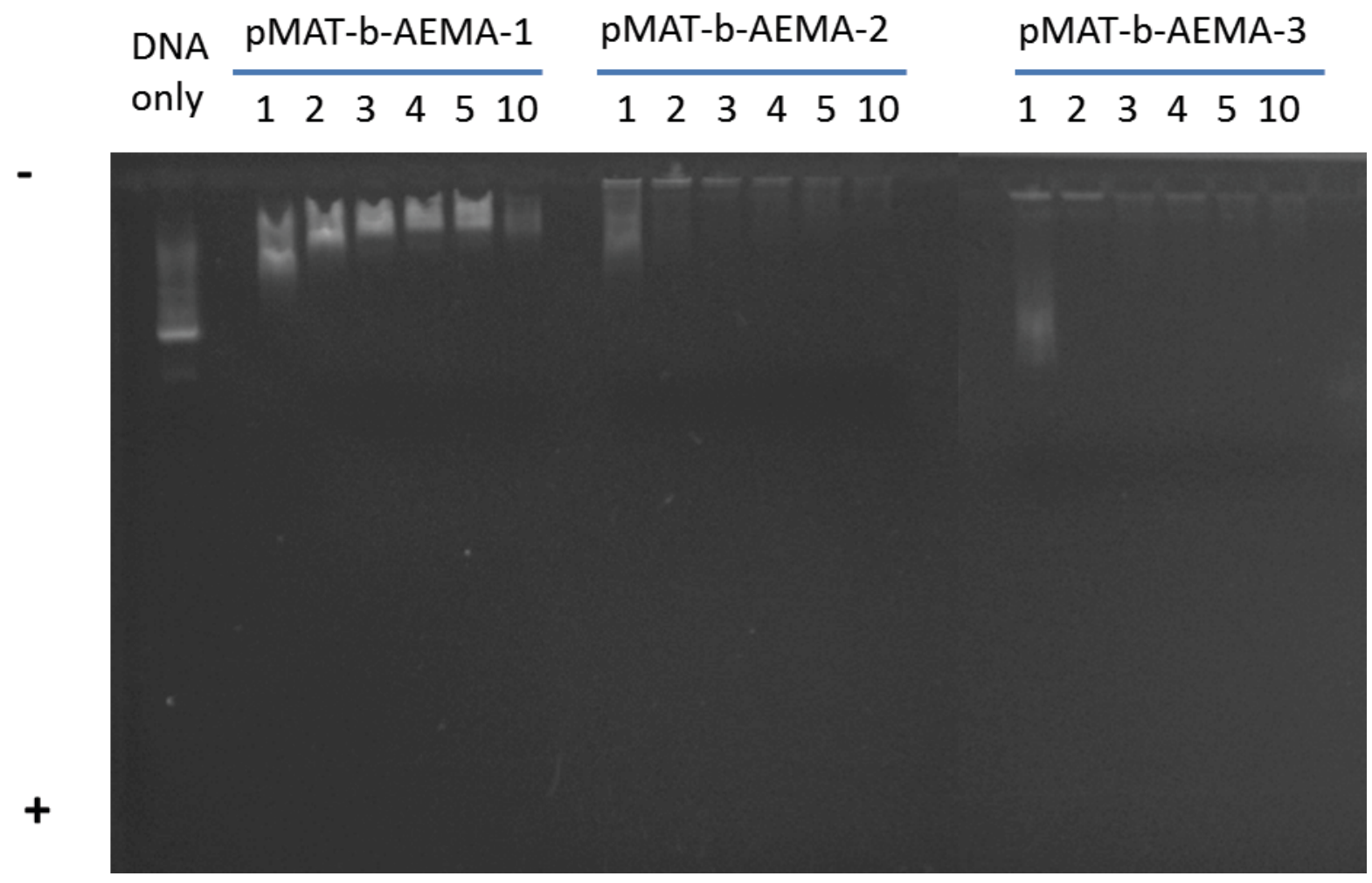

Figure S7. Gel electrophoresis mobility shift assay of polyplexes at various N/P. All three polymers show complete binding of DNA by $\mathrm{N} / \mathrm{P}=3$.

Dynamic Light Scattering (DLS)

DLS experiments were run in DMEM containing 10\% FBS. Briefly, polyplexes were formulated at N/P 7, 14, and 21 in $\mathrm{H}_{2} \mathrm{O}$ and incubated for $1 \mathrm{~h}$ at a concentration of $200 \mu \mathrm{M}$ in pDNA (to allow complexation) before being diluted withDMEM containing 10\% FBS by volume. For DLS studies prior to lyophilization, the polyplexes were diluted to a final concentration of $100 \mu \mathrm{M}(\mathrm{T}$ $=0 \mathrm{~h}$ ). For the post-lyophilization DLS, polyplexes were prepared and lyophilized as previously described, reconstituted with water for 1 hour, then diluted with DMEM with 10\% FBS to 133 $\mu \mathrm{M}$. Size measurements were taken at $25^{\circ} \mathrm{C}$ using a $173^{\circ}$ detection angle at times of $0 \mathrm{~h}, 1 \mathrm{~h}, 2 \mathrm{~h}$, and $4 \mathrm{~h}$. 

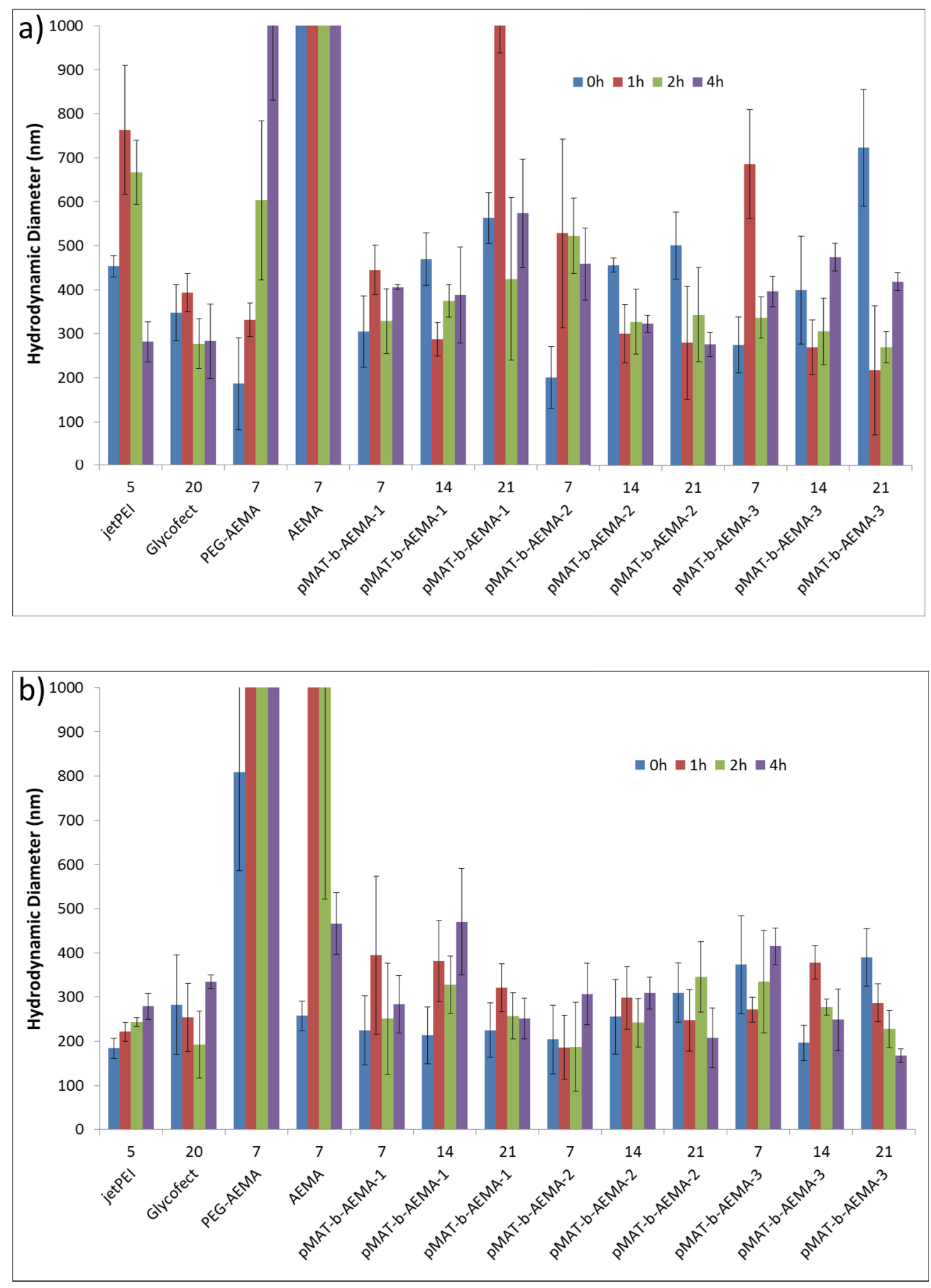

Figure S8. Polyplex hydrodynamic diameters determined by DLS in DMEM plus 10\% FBS after a) one round of lyophilization then b) a second round of lyophilization. Each measurement is the average of three data points with error bars representing the standard deviation. 


\section{Transmission Electron Microscopy (TEM) Imaging}

$3 \mu \mathrm{L}$ of polyplex solution (formulated with pDNA and polymers pMAT-b-AEMA-1, -2, or -3) prepared at $\mathrm{N} / \mathrm{P}=10$ were applied to a 300-mesh carbon coated copper grid (Ted Pella, Inc., Redding, CA). Excess solution was removed with filter paper after $60 \mathrm{~s}$. Negative stain $(3.0 \mu \mathrm{L}$ $1 \%$ uranyl acetate solution) was applied in triplicate to the sample to facilitate visualization. Images were recorded using Eagle ${ }^{\mathrm{TM}} 2 \mathrm{k}$ CCD camera, and phase contrast was enhanced at 10 to $12 \mu \mathrm{m}$ underfocus. Images were saved as TIFF files and analyzed by counting pixels in Microsoft Paint. Image S9 below summarizes the image analyses.

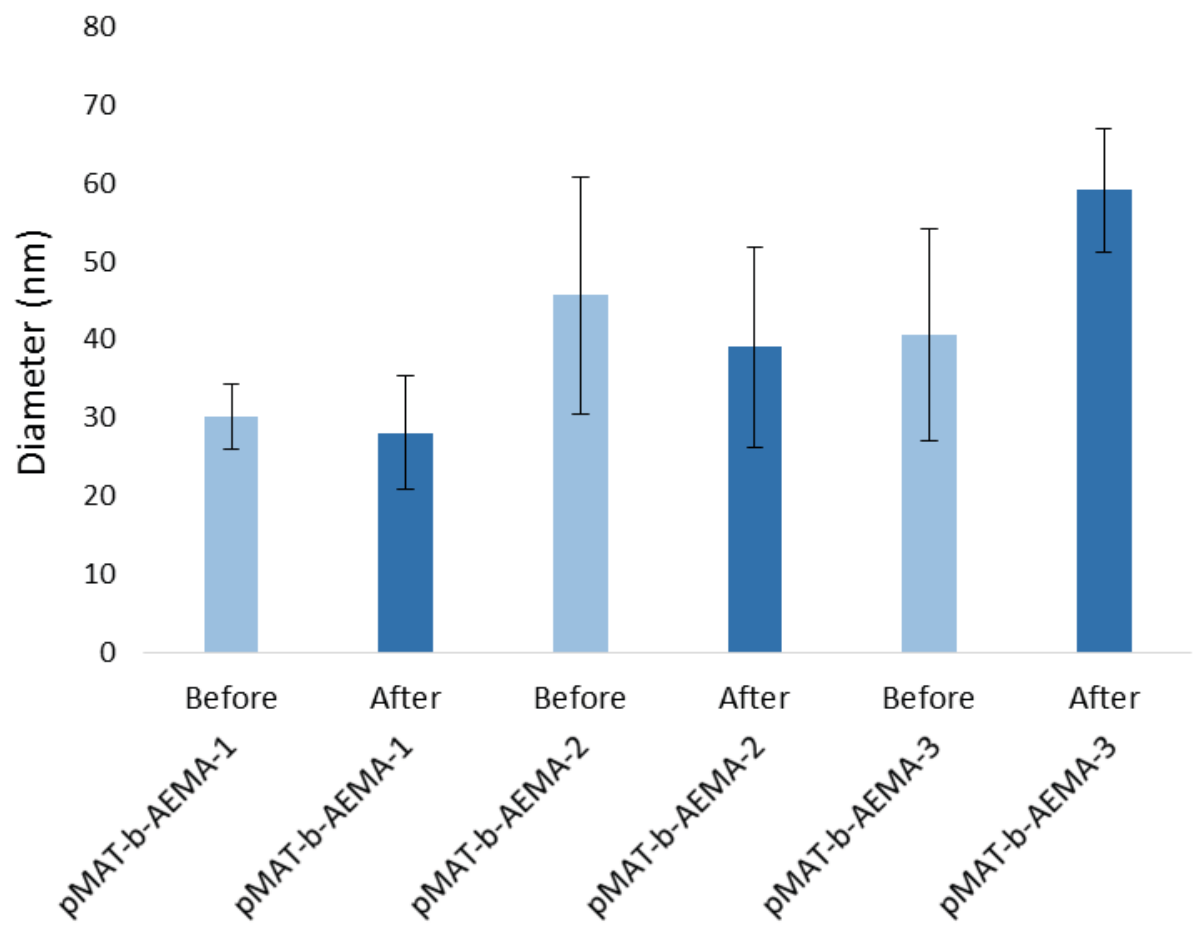

Figure S9. Polyplex diameter as measured by analysis of TEM images. Each data point is the average of at least eight polyplexes in each sample, and the standard deviation is shown by the error bar.

\section{Lyophilization}

For studies involving lyophilization, polyplexes were formulated following the previously described procedure at a final concentration of $200 \mu \mathrm{M}$ in $\mathrm{H}_{2} \mathrm{O}$. The polyplexes were incubated at $23{ }^{\circ} \mathrm{C}$ for $1 \mathrm{~h}$ then frozen in liquid nitrogen and freeze dried on a VirTis benchtopK lyophilizer 
at $62 \mathrm{mT}$ with a condenser at $-57.4^{\circ} \mathrm{C}$. The lyophilized powder was reconstituted to $200 \mu \mathrm{M}$ in $\mathrm{H}_{2} \mathrm{O}$ and allowed to incubate at $23{ }^{\circ} \mathrm{C}$ for $1 \mathrm{~h}$ before proceeding with the relevant assay.

\section{Cell Culture Experiments}

\section{$\underline{\text { MTT Assay }}$}

MTT (3-(4, 5-dimethylthiazol-2-yl)-2, 5-diphenyltetrazolium bromide) was used to estimat

e the cytotoxicity of the polyplexes. MTT is reduced to purple formazan in living cells via mitochondrial reductase. HepG2 or U87 cells were seeded at 50,000 cells/well in 24-well plates $24 \mathrm{~h}$ prior to transfection. Polyplexes were formed following the previously described procedure. Polyplexes were formulated as described above and transfection media (200 $\mu \mathrm{L}$ of either OptiMEM or DMEM containing 10\% FBS) was added to each well; $4 \mathrm{~h}$ later, complete DMEM containing 10\% FBS ( $1 \mathrm{ml})$ was added to each well. Following $24 \mathrm{~h}$, the media was aspirated and cells were washed with PBS (500 $\mu \mathrm{L} /$ well). 10\% FBS supplemented DMEM (1 mL) with 0.5 $\mathrm{mg} / \mathrm{mL}$ of MTT was added to each well and incubated for $1 \mathrm{~h}$. The media was then replaced with $600 \mu \mathrm{L}$ of DMSO for $15 \mathrm{~min}$ at $23{ }^{\circ} \mathrm{C}$ to promote cell lysis. $200 \mu \mathrm{L}$ aliquots were transferred to a well of a 96-well plate for analysis by colorimeter with wavelength at $570 \mathrm{~nm}$. Non-transfected cells were used for normalizing the data. 

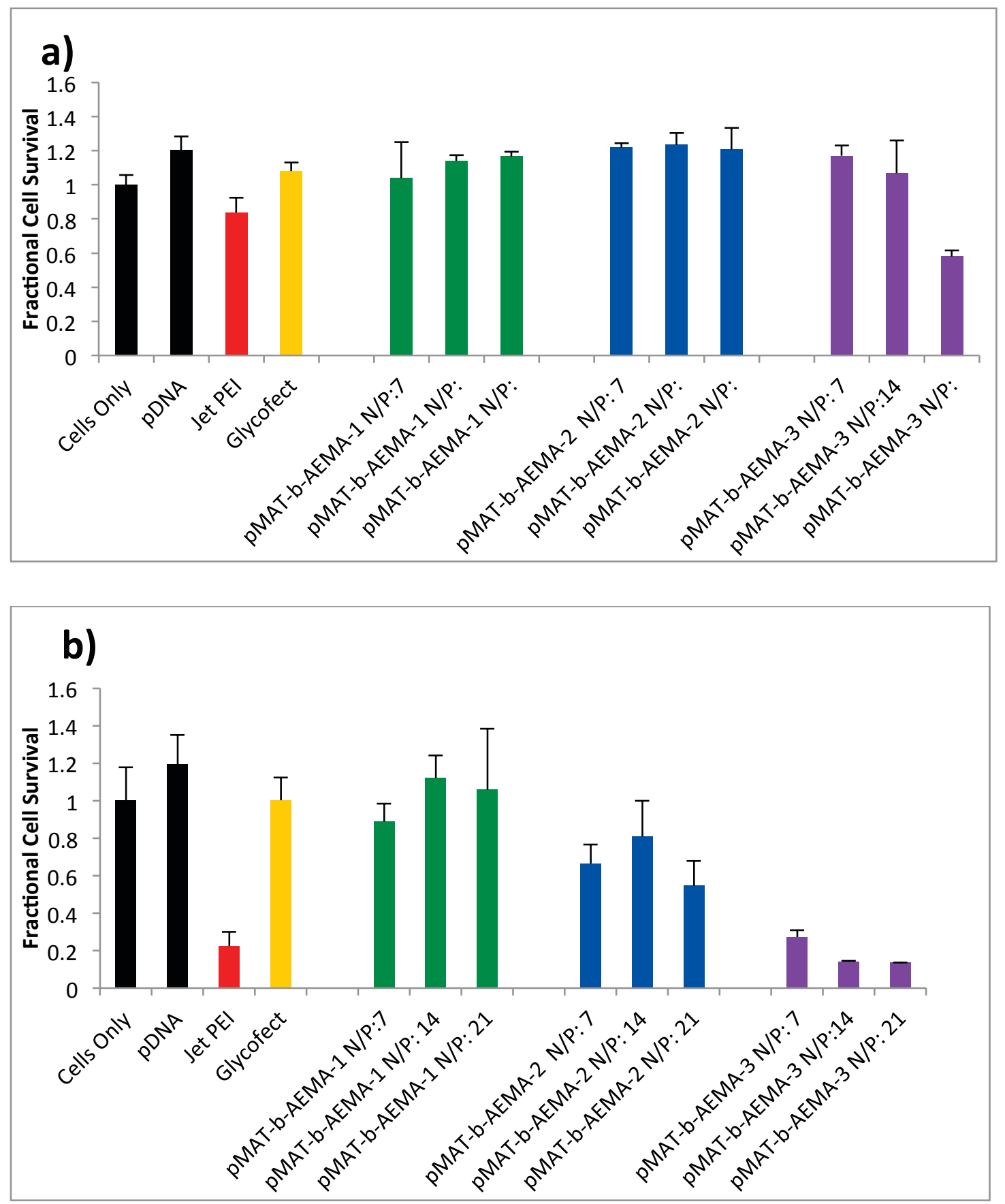

Figure S10. Cell survival following incubation of cells with pMAT-b-AEMA-1, -2, and -3 polyplexes for $48 \mathrm{~h}$ in Opti-MEM with a) HepG2 cells and b) U87 cells at N/P ratios of 7, 14, 21. All results are normalized to a control sample containing cells that underwent no treatment and were allowed to proliferate normally for 48 hours in Opti-MEM (Cells Only). Bars represent the average of three separate experiments and error bars represent the standard deviation. 


\section{Cellular Uptake Assay}

Flow cytometry was performed to examine the cellular uptake of Cy5-labeled pDNA 4 h posttransfection. HepG2 or U87 cells were seeded at 300,000 cells/well in 6-well plates $24 \mathrm{~h}$ prior to transfection. To transfect the cells, $66 \mu \mathrm{L}$ of polyplex solution were prepared following the previously described protocol above. Each polyplex solution was added into 1,584 $\mu \mathrm{L}$ of prewarmed $\left(36{ }^{\circ} \mathrm{C}\right)$ either Opti-MEM or DMEM containing $10 \%$ FBS; $500 \mu \mathrm{L}$ was added to each well. After $4 \mathrm{~h}$, the media was removed and cells were exposed to trypsin $(0.05 \%(\mathrm{w} / \mathrm{v}), 500$ $\mu \mathrm{L} /$ well) for $3 \mathrm{~min}$ to detach the cells from the plate, then complete DMEM (500 $\mu \mathrm{L} /$ well) was added to inhibit further digestion. Cell suspensions were collected and centrifuged at $1000 \mathrm{rpm}$ for 10 min at $4{ }^{\circ} \mathrm{C}$ (Eppendorf 5810R centrifuge). The supernatant was removed and cells were washed twice with $0.5 \mathrm{~mL}$ PBS and centrifuged to remove any non-internalized polyplexes. Finally, $1 \mathrm{~mL}$ PBS was added and the cellular suspensions were kept on ice prior to flow cytometer analysis. Propidium iodide $(1.0 \mathrm{mg} / \mathrm{mL}, 2.5 \mu \mathrm{L})$ was added prior to analysis. Twenty thousand events were counted for each sample. The threshold fluorescence level was defined by manually adjusting the positive region such that $<1 \%$ of negative control cells were positive for fluorescence. Each experiment was performed in triplicate. 

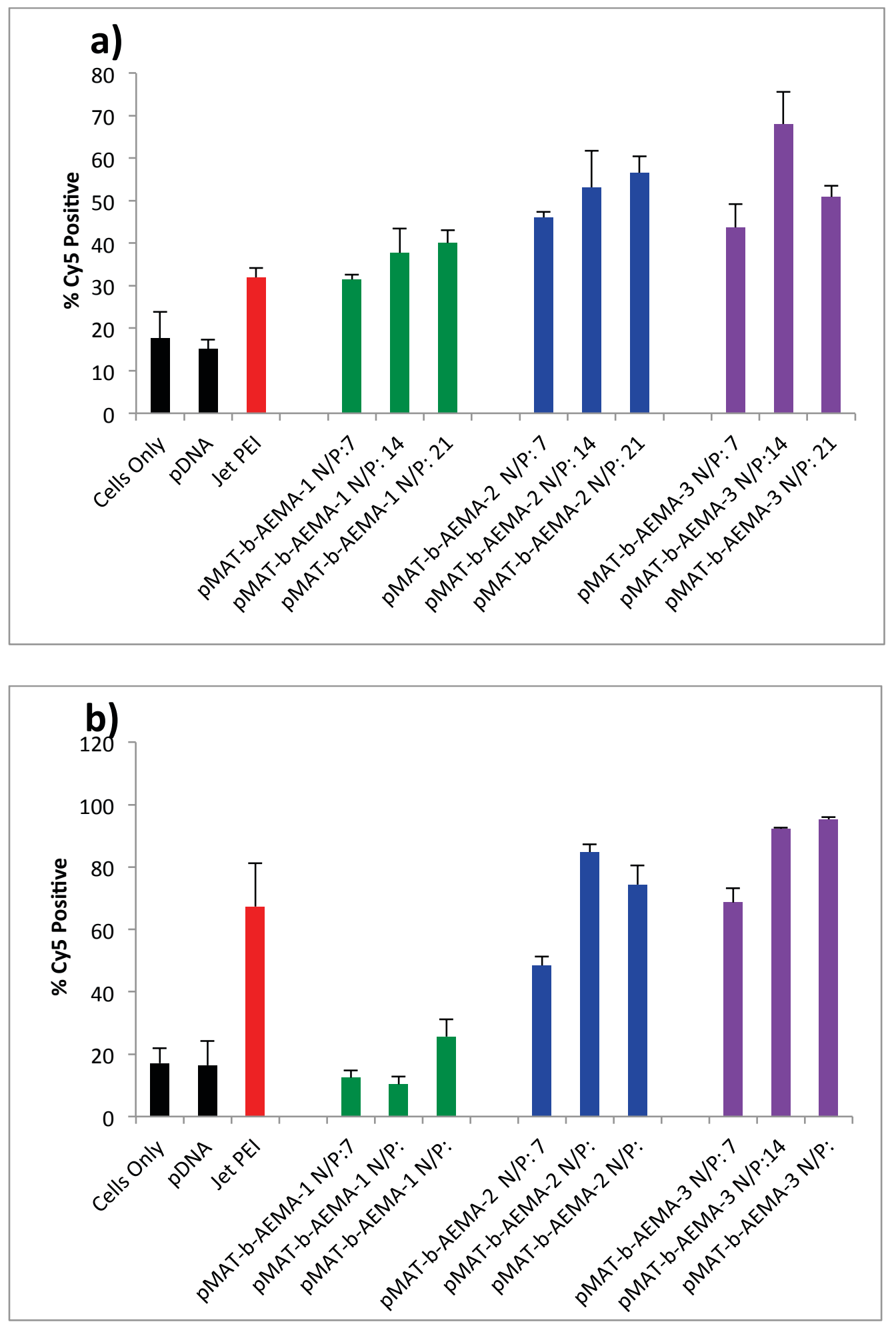

Figure S11. Cellular uptake of pMAT-b-AEMA-1, -2, and -3 polyplexes formed with Cy5labeled pDNA at N/P ratios of 7, 14, and 21 and incubated with cells for $4 \mathrm{~h}$ in Opti-MEM in a) 
HepG2and b) U87 cells. Bars represent the average of three separate experiments and error bars represent the standard deviation.

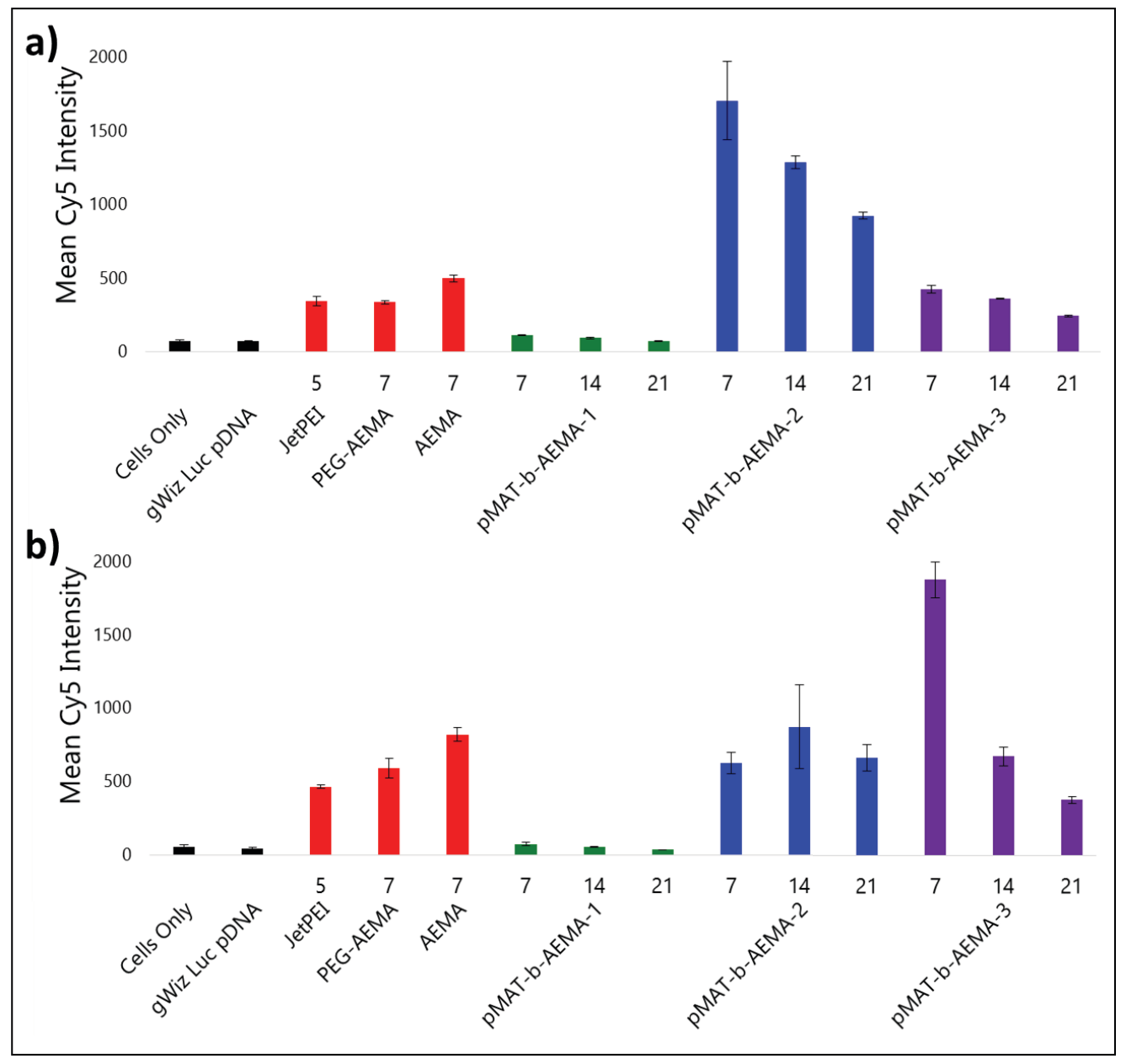

Figure S12. Cellular uptake plotted by mean fluorescence intensity of pMAT-b-AEMA-1, -2, and -3 polyplexes formed with Cy5-labeled pDNA at N/P ratios of 7, 14, and 21 and incubated with cells for $4 \mathrm{~h}$ in DMEM in a) HepG2 and b) U87 cells. Bars represent the average of three separate experiments and error bars represent the standard deviation.

\section{Luciferase Gene Expression}

Cells (HepG2 and U-87) were seeded at 50,000 cells/well in 24-well plates $24 \mathrm{~h}$ prior to transfection. Polyplexes were prepared following the previously described procedure described above. Polyplex solutions were diluted with pre-warmed $\left(37^{\circ} \mathrm{C}\right)$ Opti-MEM or DMEM with 
$10 \%$ FBS. Cells were washed with PBS before the addition of $200 \mu \mathrm{L}$ of the transfection solution.

Cells were incubated with polyplex solutions for $4 \mathrm{~h}$ before complete DMEM (1 mL) was added. After $48 \mathrm{~h}$, the cells were washed with $500 \mu \mathrm{L}$ of PBS and treated with 1x cell lysis buffer for 15 min at $23{ }^{\circ} \mathrm{C}$. Aliquots $(5 \mu \mathrm{L})$ of cell lysate were examined on 96-well plates with a luminometer for luciferase activity with a $10 \mathrm{~s}$ scan with $100 \mu \mathrm{L}$ of luciferase substrate added in each well immediately prior to relative light unit (RLU) determination. The average of duplicate fluorescence measurements was utilized for each sample calculation and each experiment was performed in triplicate.

The amount of protein $(\mathrm{mg})$ in cell lysates was calculated using a standard curve generated with bovine serum albumin by following the protocol included in Bio-Rad DC protein assay kit. The relative light unit (RLU/mg) protein was then calculated and averaged across replicate wells for comparison. The protein and luciferase levels of non-transfected cells were used for normalizing the data and each experiment was performed in triplicate. 

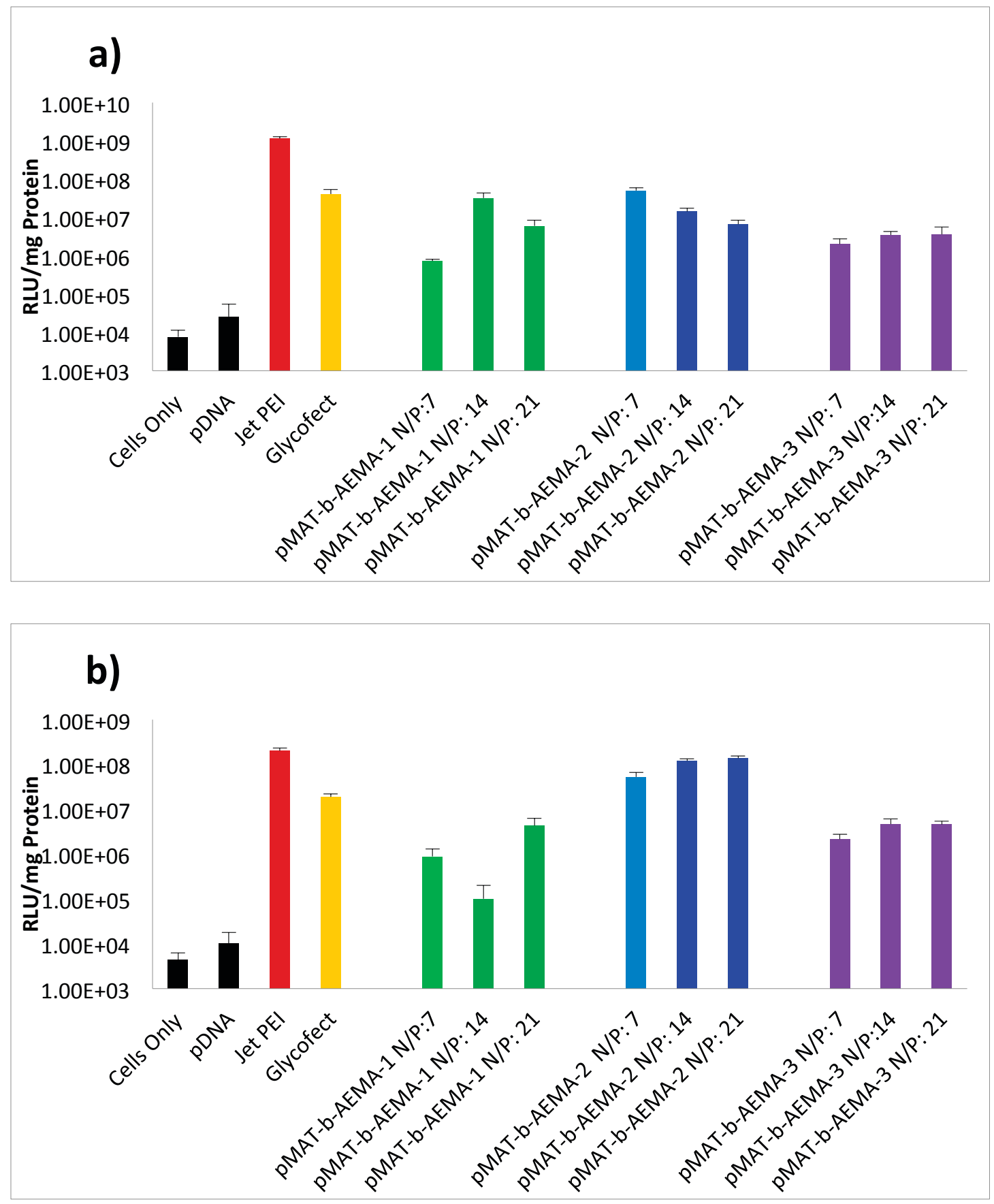

Figure S13. Luminescence of cell lysate following addition of luciferin in a) HepG2 cells and b) U87 cells. Cells were incubated with pMAT-b-AEMA polyplexes for $4 \mathrm{~h}$ in Opti-MEM followed by $48 \mathrm{~h}$ in full cell growth medium. Bars represent the average of three separate experiments and error bars represent the standard deviation. 


\section{$\underline{\text { Tail Vein Injections }}$}

Wild-type (WT) C57BL/6J 6wk-old mice were purchased from Jackson Laboratories (Sacramento, CA). All mice were maintained under AAALAC-accredited (Association for Assessment and Accreditation of Laboratory Animal Care) specific pathogen-free conditions. Appropriate amounts of polyplexes (10 $\mu \mathrm{g}$ or $25 \mu \mathrm{g}$ of pDNA/dose at desired N/P of polymer) were prepared in a 5\% by weight aqueous dextrose solution (D5W, Hospira, Inc.), and a $200 \mu \mathrm{L}$ dose of polyplexes was injected through the tail vein of experimental animals. After injection, animals were returned to their colony. Mice were imaged for transgene expression about 24 and $48 \mathrm{~h}$ after injection of the DNA solution.

\section{$\underline{\text { Hydrodynamic Injections }}$}

Wild-type (WT) C57BL/6J 6wk-old mice were purchased from Jackson Laboratories. All mice were maintained under AAALAC-accredited, specific pathogen-free conditions. Appropriate amounts of plasmid DNA were prepared in D5W solution and injected through the tail vein of experimental animals using a hydrodynamics-based procedure as previously described. ${ }^{3}$ Briefly, animals to be injected were weighed. A DNA solution volume equivalent to $10 \%$ of the weight of the mouse was calculated. Animals were anesthetized with a ketamine cocktail as per protocol. All animals were injected with the appropriate DNA solution in 3 to $4 \mathrm{~s}$. After injection, animals were placed on a heating pad to recover and returned to their colony. Mice were imaged for transgene expression about 24 and $48 \mathrm{~h}$ after injection of the DNA solution.

\section{Bioluminescence Imaging In Vivo}

$100 \mu \mathrm{L}$ of luciferin substrate solution $(28.5 \mathrm{mg} / \mathrm{mL})$ was injected intraperitoneally to each mouse. 3 to 5 min later, mice were imaged for 1 min using a Xenogen Spectrum CCD camera system (Xenogen, Alameda, CA) according to the manufacturer's instructions. Each experiment was performed in triplicate.

\section{Euthanizing and Tissue Collection/Processing}

Mice were euthanized by $\mathrm{CO}_{2}$ (carbon dioxide) inhalation, perfused with saline, and selected organs were resected and preserved for analyses. Plasma and tissues were stored at $-80{ }^{\circ} \mathrm{C}$. Frozen liver tissues were homogenized by mortar and pestle, and a $100 \mathrm{mg}$ tissue sample was 
removed for DNA processing. All other tissues were resected from the body and placed in DNA extraction solution directly. DNA extraction solution was comprised of Qiagen Cell Lysis buffer (Qiagen, Germantown, MD) and Proteinase K (20 mg/mL; Fisher Scientific, Fair Lawn, NJ). $700 \mu \mathrm{L}$ of Qiagen Cell lysis buffer and $10 \mu \mathrm{L}$ Proteinase $\mathrm{K}$ were added to each sample. The samples were placed at $55{ }^{\circ} \mathrm{C}$ overnight. DNA extraction was performed by phenol-chloroform extraction and ethanol precipitation. DNA purity and amount were determined by using a NanoDrop instrument.

qPCR

DNA samples were normalized to $100 \mathrm{ng} / \mu \mathrm{L}$. $500 \mathrm{ng}$ of DNA was used with the TaqMan Gene Expression Master Mix (Life Technologies - Thermo Fisher Scientific, Carlsbad, CA). TaqMan primers were designed and manufactured by Life Technologies - Thermo Fisher Scientific (Carlsbad, CA), Custom Plus TaqMan Assay, Assay ID - AJ6RNJ4. All DNA and reagents were kept on ice. Master mix consisting $10 \mu \mathrm{L}$ of $2 \times$ reaction mix, $1 \mu \mathrm{L}$ TaqMan assay and $7 \mu \mathrm{L}$ RT-PCR Grade water (Ambion, Life Technologies - Thermo Fisher, Inc., Carlsbad, CA) per sample was prepared. A volume of $5 \mu \mathrm{L}$ (500 ng) DNA was added to Master mix on ice and mixed gently by hand. No template controls were made using RT-PCR Grade water (Ambion). A standard curve was prepared by serially diluting pT2/CaL plasmid into WT C57BL/6 DNA. Samples were run using the impulse setting. The following conditions were used for the qPCR: $95^{\circ} \mathrm{C}$ for $10 \mathrm{~min}$ and 40 cycles of $90{ }^{\circ} \mathrm{C}$ for $15 \mathrm{~s}$ then $60{ }^{\circ} \mathrm{C}$ for $1 \mathrm{~min}$. See data below in Table S1 where 0.1-1.0 plasmid copies/cell values are background. 
Table 2. Average number of copies per genome equivalent (cell) of pDNA as measured with qPCR in the liver, brain, spleen, heart, kidney, and lungs of mice treated with polyplexes of pMAT-b-AEMA-2 and pDNA encoded for luciferase via tail vein injection. Plasmid values from $0-1.0$ are considered background noise.

\begin{tabular}{|c|c|c|c|c|c|c|c|c|c|c|}
\hline \multicolumn{4}{|c|}{ Tail Vein Injection Details } & \multirow[b]{2}{*}{$\begin{array}{l}\text { Number } \\
\text { of Mice }\end{array}$} & \multicolumn{6}{|c|}{ DNA in Organ (Average Plasmid Copies/Cell) } \\
\hline & $\begin{array}{l}\text { Polymer } \\
\text { Dose (mg) }\end{array}$ & $\begin{array}{l}\text { DNA } \\
\text { Dose } \\
(\mu \mathrm{g})\end{array}$ & $\mathbf{N} / \mathbf{P}$ & & Liver & Brain & Spleen & Heart & Kidney & Lung \\
\hline \multirow{4}{*}{$\begin{array}{l}\text { pMAT-b- } \\
\text { AEMA-2 }\end{array}$} & 200.0 & 10 & 7 & 3 & 0.01 & 0.8 & 1.0 & 0.7 & 0.5 & 0.9 \\
\hline & 390.0 & 10 & 14 & 3 & 0.80 & 0.9 & 0.3 & 0.8 & 0.1 & 2.9 \\
\hline & 590.0 & 10 & 21 & 3 & 0.10 & 0.9 & 1.3 & 2.0 & 0.6 & 6.5 \\
\hline & 490.0 & 25 & 7 & 3 & 1.60 & 0.9 & 0.5 & 1.0 & 0.1 & 1.1 \\
\hline $\mathrm{D}_{5} \mathrm{~W}$ & N/A & N/A & N/A & 2 & 0.2 & 0.1 & 0.1 & 0.2 & 0.1 & 1.0 \\
\hline
\end{tabular}

\section{References}

(1) Sizovs, A.; Xue, L.; Tolstyka, Z. P.; Ingle, N. P.; Wu, Y. Y.; Cortez, M.; Reineke, T. M. J. Am. Chem. Soc. 2013, 135, 15417.

(2) Belur, L. R.; Podetz-Pedersen, K.; Frandsen, J.; McIvor, R. S. Nat. Protoc. 2007, 2, 3146.

(3) Bell, J. B.; Podetz-Pedersen, K. M.; Aronovich, E. L.; Belur, L. R.; McIvor, R. S.; Hackett, P. B. Nat. Protoc. 2007, 2, 3153. 